\begin{tabular}{|l|c|c|c|r|}
\hline $\begin{array}{l}\text { Cuadernos de Investigación Geográfica } \\
\text { Geographical Research Letters }\end{array}$ & 2018 & N $^{\circ} 44(1)$ & pp. 115-136 & $\begin{array}{r}\text { ISSN 0211-6820 } \\
\text { eISSN 1697-9540 }\end{array}$ \\
\hline
\end{tabular}

DOI: http://doi.org/10.18172/cig.3363

\title{
LITTLE ICE AGE GLACIER HISTORY OF THE CENTRAL AND WESTERN ALPS FROM PICTORIAL DOCUMENTS
}

\author{
H.J. ZUMBÜHL ${ }^{1}$, S.U. NUSSBAUMER ${ }^{2,3}$ \\ ${ }^{1}$ Institute of Geography, University of Bern, Switzerland \& Oeschger Centre \\ for Climate Change Research, University of Bern, Switzerland. \\ ${ }^{2}$ Department of Geography, University of Zurich, Switzerland. \\ ${ }^{3}$ Department of Geosciences, University of Fribourg, Switzerland.
}

\begin{abstract}
The Lower Grindelwald Glacier (Bernese Oberland, Switzerland) consists of two parts, the Ischmeer in the east (disconnected) and the Bernese Fiescher Glacier in the west. During the Little Ice Age (LIA), the glacier terminated either in the area of the "Schopffelsen" (landmark rock terraces) or advanced at least six times (ten times if we include early findings) even further down into the valley bottom forming the "Schweif" (tail). Maximal ice extensions were reached in 1602 and 1855/56 AD. The years after the end of the LIA have been dominated by a dramatic melting of ice, especially after 2000. The Mer de Glace (Mont Blanc area, France) is a compound valley glacier formed by the tributaries Glacier du Tacul, Glacier de Léschaux, and Glacier de Talèfre (disconnected). During the LIA, the Mer de Glace nearly continuously reached the plain in the Chamonix Valley (maximal extensions in 1644 and 1821 AD). The retreat, beginning in the mid-1850s, was followed by a relatively stable position of the front (1880s until 1930s). Afterwards the retreat has continued until today, especially impressive after 1995. The perception of glaciers in the early times was dominated by fear. In the age of Enlightenment and later in the 19th century, it changed to fascination. In the 20th century, glaciers became a top attraction of the Alps, but today they are disappearing from sight. With a huge number of high-quality pictorial documents, it is possible to reconstruct the LIA history of many glaciers in the European Alps from the 17th to the 19th centuries. Thanks to these pictures, we get an image of the beauty and fascination of LIA glaciers, ending down in the valleys. The pictorial documents (drawings, paintings, prints, photographs, and maps) of important artists (Caspar Wolf, Jean-Antoine Linck, Samuel Birmann) promoted a rapidly growing tourism. Compared with today's situations, it gives totally different landscapes - a comparison of LIA images with the same views of today is probably the best visual proof for the changes in climate.
\end{abstract}




\section{La historia glaciar de la Pequeña Edad del Hielo en los Alpes Centrales y Occidentales a partir de documentos pictóricos}

RESUMEN. El glaciar inferior de Grindelwald (Oberland bernés, Suiza) consta de dos partes, el glaciar Ischmeer, al este (desconectado), y el Fiescher bernés, al oeste. Durante la Pequeña Edad del Hielo (PEH), el glaciar terminó en el área de "Schopffelsen" (terrazas de roca), es decir avanzó al menos seis veces más (diez veces si incluimos hallazgos tempranos) alcanzando el fondo del valle y formando una "Schweif" (cola). Las extensiones máximas de hielo se registraron en 1602 y en 1855/56 AD. Los años posteriores al final de la PEH han estado dominados por un dramático derretimiento del hielo, especialmente después del año 2000. El Mer de Glace (área del Mont Blanc, Francia) es un glaciar configurado a partir de los glaciares de Tacul, Léschaux y Talèfre (desconectado). Durante la PEH, el Mer de Glace alcanzó casi de forma permanente el valle de Chamonix (extensiones máximas en 1644 y en 1821 AD). El retroceso del hielo, que comenzó a mediados de 1850, fue seguido por una posición relativamente estable del frente (de los años 1880 hasta 1930). Posteriormente, el retroceso ha continuado hasta hoy, especialmente destacado desde 1995. La percepción de los glaciares en los primeros tiempos estuvo dominada por el miedo. En la época de la Ilustración y más tarde en el siglo XIX el miedo dio paso a la fascinación. En el siglo XX, los glaciares se convirtieron en la principal atracción de los Alpes, pero hoy están desapareciendo de nuestra vista. Con un gran número de documentos pictóricos de alta calidad es posible reconstruir la historia del PEH de muchos glaciares en los Alpes europeos desde los siglos XVII al XIX. Gracias a esta documentación, se obtiene una imagen de la belleza y fascinación de los glaciares de la PEH terminando en los fondos de valle. Los documentos pictóricos (dibujos, pinturas, grabados, fotografías y mapas) de importantes artistas (Caspar Wolf, Jean-Antoine Linck, Samuel Birmann) ayudaron a promover un turismo en rápida expansión. Comparados con la situación de hoy día, estos documentos ofrecen paisajes totalmente diferentes. Una comparación de las imágenes PEH con la visión actual es probablemente la mejor prueba de los efectos de los cambios climáticos.

Key words: glacier fluctuations, pictorial documents, Lower Grindelwald Glacier, Mer de Glace, European Alps, Little Ice Age (LIA).

Palabras clave: fluctuaciones glaciares, documentos pictóricos, glaciar inferior de Grindelwald, Mer de Glace, Alpes europeos, Pequeña Edad del Hielo.

Received: 6 July 2017 Accepted: 25 August 2017

Corresponding author: Heinz J. Zumbühl, Institute of Geography, University of Bern, Switzerland \& Oeschger Centre for Climate Change Research, University of Bern, Switzerland. E-Mail address: zumbuehl@giub.unibe.ch

\section{Introduction}

Glaciers fluctuate in response to changes in climate, and are therefore prime climate indicators (IPCC, 2013; Marzeion et al., 2014). Climate conditions (lower temperatures 
and wet summers) during the Little Ice Age (LIA) - a period from about 1350 to 1850 $\mathrm{AD}$ - enabled glaciers in the European Alps to extend far down valleys, threatening human lives and infrastructures (e.g., Grove, 2004). The glacier iconography of this period celebrates the beauty and grandeur of ice in close vicinity to human settlements, a leading touristic attraction in the Alps at the time. These past glacier advances stand in contrast to today's rapid and possibly unprecedented retreat of glaciers worldwide (Zemp et al., 2015).

In order to better assess and predict present and future glacier losses, recent changes can be compared to past glacier fluctuations. Taken together, data on climate conditions (e.g., PAGES 2k Consortium, 2013) and glacier extents (e.g., Solomina et al., 2015) during the LIA provide valuable insight into glacier responses to climate in the recent past. In this paper, we discuss the LIA glacier history of the Central and Western Alps. We focus on the Lower Grindelwald Glacier (Bernese Oberland, Switzerland) and the Mer de Glace (Mont Blanc massif, France), two iconic glaciers for which a wealth of pictorial documents are available from this period.

\section{Methods to reconstruct historical glacier changes}

Historical documents - including pictorial works (e.g., drawings, paintings, prints, photographs), cartography (e.g. maps, cadastral plans, reliefs), and written accounts (e.g., chronicles, church registers, land sale contracts, travel guides, early scientific works) have proven particularly valuable for quantifying glacier changes over recent centuries, including the LIA (Zumbühl et al., 2016). When sufficient in quality and quantity, these documents provide a detailed picture of glacier fluctuations, in particular, frontal length changes. Prior to 1800 , the abundance of historical documents about European glaciers depends mainly on the proximity of glacier tongues - and the threat of further glacier advance - to human settlements and cultivated land. Using such documents, we have reconstructed decadal to annual time series of glacier extent for the Lower Grindelwald Glacier and the Mer de Glace (Zumbühl et al., 2008).

Historical documents must be interpreted with care, taking local circumstances into account. In particular, pictorial works must fulfil several requirements in order to yield reliable quantitative results concerning the former extents of glaciers (Zumbühl, 1980):

(i) The exact date of the depicted scene must be known. Oil paintings, although typically started onsite, were often finished and dated later in the studio, while prints often bear a different date than the original drawings. Dating early glacier photographs can be especially difficult, and often includes time-consuming archival work.

(ii) The glacier and its surroundings need to have been rendered in a manner consistent with physical reality, which requires particular skills by the artist.

(iii) The artist's viewing position must be known. This can be estimated from prominent features surrounding the glacier, such as rock steps, hills, or mountain peaks. 

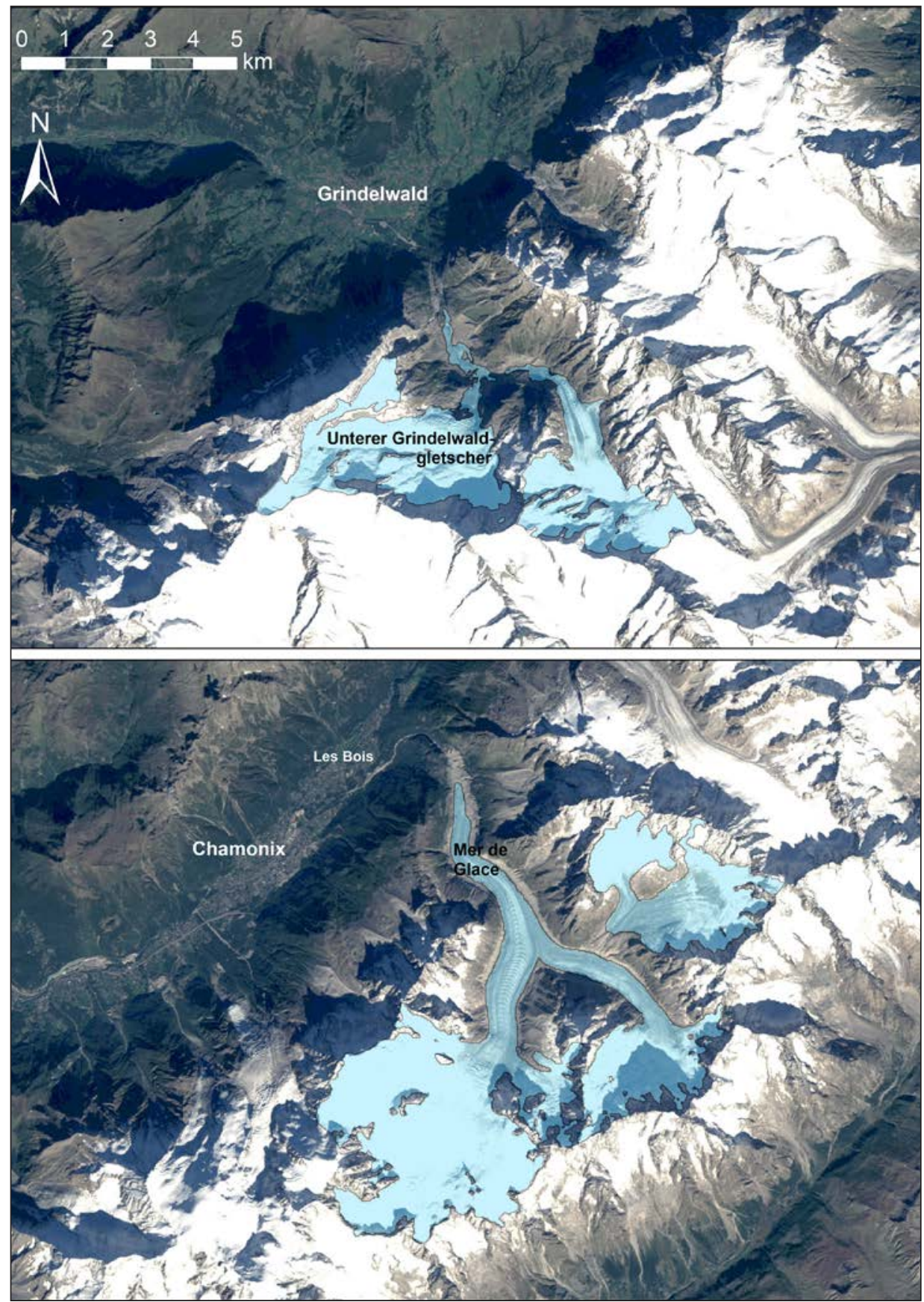

Figure 1. Outlines of Lower Grindelwald Glacier (Bernese Oberland, Switzerland) and Mer de Glace (Mont Blanc massif, France) on a Landsat 5 satellite image from 25 September 2013 (source: U.S. Geological Survey). 


\section{Lower Grindelwald Glacier: the best-documented glacier of the Central Alps (historical records since the 12th century)}

The Lower Grindelwald Glacier $\left(46^{\circ} 35^{\circ} \mathrm{N}, 8^{\circ} 05^{\prime} \mathrm{E}\right.$; Fig. 1) is an 8.2-km long, $17.8 \mathrm{~km}^{2}$ valley glacier (as of 2012) formed by the confluence of the Upper and Lower Ischmeer in the east and the Bernese Fiescher Glacier in the west. It is quite possibly the best-documented glacier in the Swiss Alps, with records reaching back to the 12th century (Holzhauser and Zumbühl, 1996, 2003; Zumbühl, 1980; Zumbühl et al., 1983, 2016). The geometry of the Lower Grindelwald Glacier differs from that of the "model" glacier in having a wide variety of surface slopes and many basins that deliver ice to the main stream.

During the LIA, the Lower Grindelwald Glacier terminated either in the area of the "Schopffelsen" (landmark rock terraces) or advanced at least six times even further down to the valley floor - or ten times if we count also the early findings in the 12th/13th centuries (1146, 1246/47, and uncertain advances). Those advances led to the formation of a marked fan-shaped tongue or tail ("Schweif"), i.e. the glacier front was advancing about 500-600 $\mathrm{m}$ over the Schopffelsen rock terraces in direction northwest downvalley to near the village of Grindelwald (Figs. 2 and 5). As a result, the number of quality written and pictorial documents from villagers, visiting artists, and later also tourists is substantial (over 400 images before 1900). From these, it is possible to reliably reconstruct the glacier's length as far back as $1535 \mathrm{AD}$, a feat that is not possible for most other Alpine glaciers.

The great advance from 1580 to 1602 brought the culmination of the LIA, when the glacier presumably reached a long lasting period of maximum ice extension. The advance recorded in the landscape as a series of moraine ridges in the valley bottom $50 \mathrm{~m}$ past the 19th century moraines, and verified by radiocarbon dating (Zumbühl et al., 2016). During these years, Joseph Plepp created the first pictorial view of the glacier's advance - an etching published in 1642 by Matthäus Merian (and copied many times in the 17th and 18 th centuries).

As seen in a watercolour pen drawing by Albrecht Kauw (Fig. 2a), the glacier was again (or still) in the valley bottom in 1669. An advance in 1719-1720 is only documented in written sources.

A unique series of oil paintings by Caspar Wolf (1735-1783; Zumbühl, 2009; Zumbühl et al., 2016) documents the glacier's advance from 1768 to 1778/79 (Fig. 2b). One of the most dramatic and most fascinating glacier views depicts the steep blue-green front of the Lower Grindelwald Glacier with sculptured seracs (ice pinnacles) in the background, a typical and distinctive feature of advancing glaciers - and also a perfect view for combining observation and staging (Fig. 7a, cut-out).

Another highlight in artistic glacier iconography are the hundred extremely precise glacier drawings made by Samuel Birmann (1793-1847), one quarter of which depict the Lower and Upper Grindelwald Glaciers (Zumbühl, 1997; Zumbühl et al., 2016). The work of Birmann is strived for realism. Following a rapid advance of the Lower Grindelwald Glacier from 1814/15, to a first culmination in 1820/22, the "Schweif" (literally tail) 
reached the valley bottom (an advance of about 450-525 m). Birmann's drawings from 1826 depict the rich variability of ice structures on the glacier tongue and the different moraines in the foreland drawn by fine pen lines (Fig. 3b). Also in the following years, the ice continuously covered big parts of the proglacial area in the valley floor.
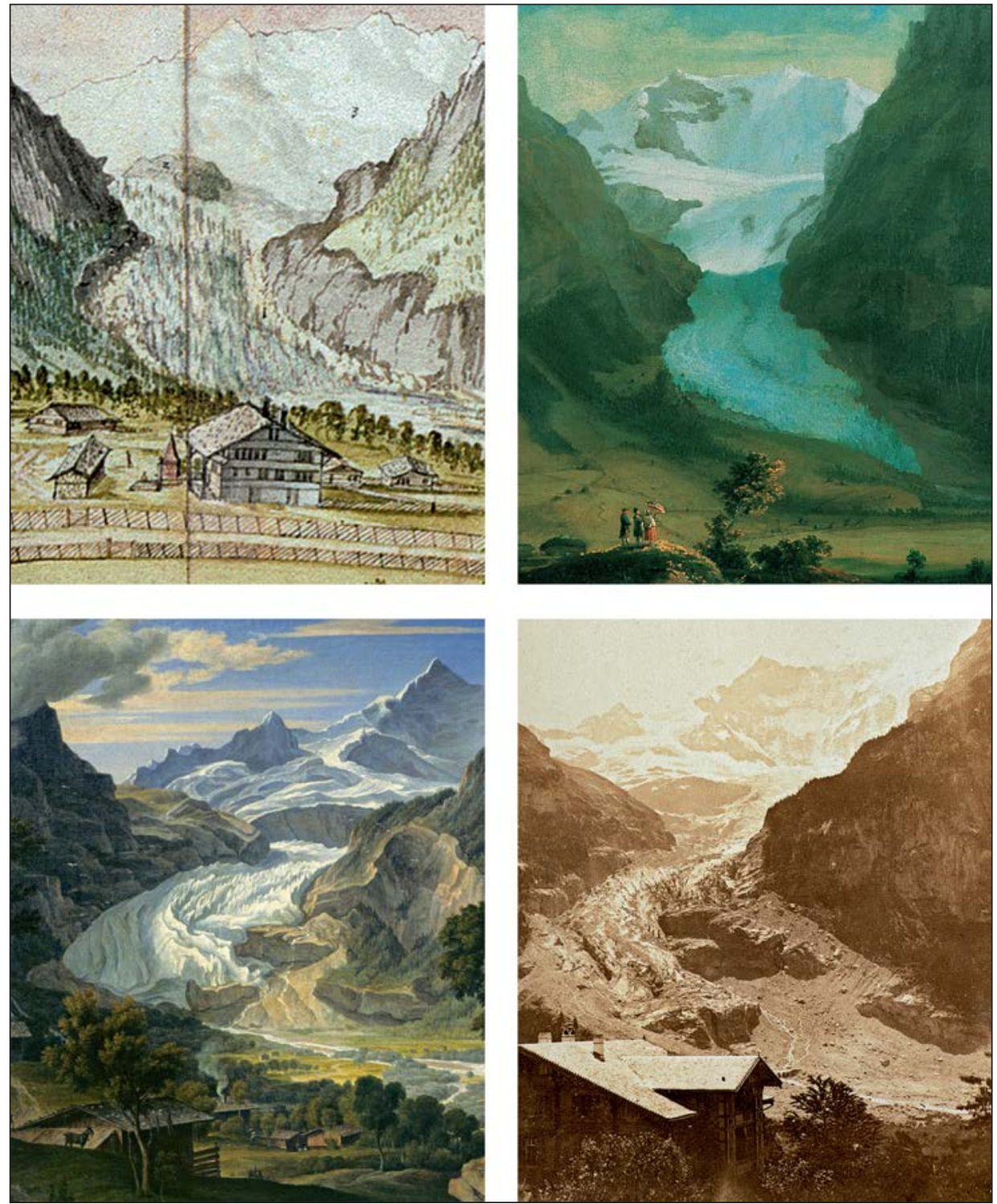

Figure 2. Lower Grindelwald Glacier through time: (a) 1669 - pen drawing and watercolour by A. Kauw (cut-out; Bernisches Historisches Museum, Bern), (b) 1774/76 - oil on canvas by C. Wolf(cut-out; Aargauer Kunsthaus, Aarau), (c) 1794 - oil on canvas by J. A. Koch (cut-out; Museum Narodowe we Wroclawiu, Wroclaw), (d) 1869 - photograph by J. Beck (Alpines Museum der Schweiz, Bern). 


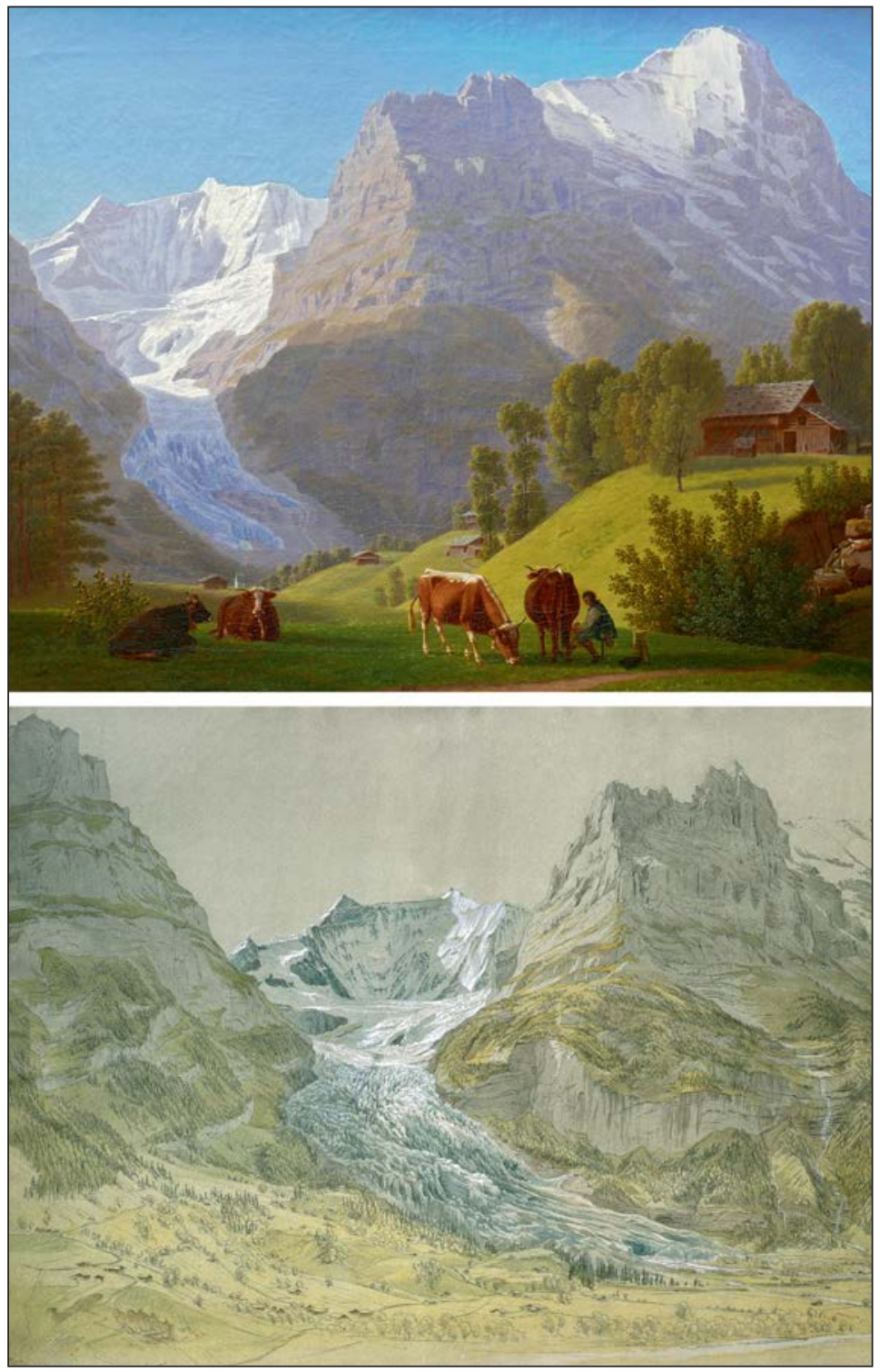

Figure 3. Tongue of the Lower Grindelwald Glacier: (a) strongly melted back on the Schopffelsen rock terraces, as drawn with oil on canvas by J. J. Biedermann in 1812 from a field survey around 1808 (private collection) and (b) forming the characteristic tail down to the valley bottom, as drawn with pencil and watercolour by S. Birmann on 9 September 1826

(Kunstmuseum Basel, Kuperstichkabinett).

Following an additional advance of $80-120 \mathrm{~m}$, the Lower Grindelwald Glacier reached a second historical maximum in 1855/56 documented by a growing number of photographs, e.g. by Frédéric Vincent de Martens (Fig. 10a). 
Between these periods of advance, the glacier front often retreated - and remained over a long period - as far back as the Lower and Upper Schopffelsen rock terraces, about 600-900 $\mathrm{m}$ from the maximum moraines in the valley bottom. This is seen first in an oil sketch made by Johann Rudolf Huber in 1705 (Zumbühl et al., 2016), then again between $1748 / 49$ and 1766, when the glacier retreated to near the entrance to the gorge. After the advance of $1778 / 79$, the front again retreated back to the rock terraces between about 1794 and 1814/15, as documented by two beautiful paintings: The Austrian Joseph Anton Koch, famous as an early realist, painted a very precise view of the Lower Grindelwald Glacier retreated to the Schopffelsen rock terraces (Fig. 2c); although completed in 1823, the glacier topography was derived from a drawing he made while visiting the site in 1794. By 1808, when painted (1812) in a more classicistic style by Johann Jakob Biedermann (Fig. 3a), the glacier had retreated even further.

The 160 years since the end of the LIA have been dominated by a nearly continuous loss of ice (only interrupted by three small and short-lived advances). Retreat was especially rapid from 1860 to 1869 and impressively documented by many photographs, e.g. by J. Beck in 1869 (Fig. 2d), with various techniques and formats ranging from highly artistic panoramas (e.g. by A. Braun; Zumbühl et al., 2016) to small stereophotograms mass-produced for the rapidly growing tourist industry.

Dramatic and sustained ice loss from an already reduced level since the beginning of the 21st century has resulted in a landscape of ruins of ice. Since 1855/56, the Lower Grindelwald Glacier has lost about 32-41\% of its length (1855/56-2014) and about half of its volume, an annual thinning rate of about $40 \mathrm{~cm}$ averaged over the entire surface (Table 1; Steiner et al., 2008; Zumbühl et al., 2016).

Table 1. Changes in glacier parameters since the LIA maximum (data sources: Nussbaumer et al., 2007; Steiner et al., 2008; Zumbühl et al., 2016).

\begin{tabular}{|c|c|c|c|c|c|c|}
\hline Glacier & \begin{tabular}{|c|} 
Lower \\
Grindelwald \\
\end{tabular} & $\begin{array}{c}\text { Lower } \\
\text { Grindelwald }\end{array}$ & \begin{tabular}{|c|} 
Lower \\
Grindelwald \\
\end{tabular} & $\begin{array}{c}\text { Mer de } \\
\text { Glace }\end{array}$ & $\begin{array}{c}\text { Mer de } \\
\text { Glace }\end{array}$ & $\begin{array}{c}\text { Mer de } \\
\text { Glace }\end{array}$ \\
\hline Year & $1860 / 61 / 72$ & 2004 & 2012 & 1821 & 1939 & 2001 \\
\hline Data source & $\begin{array}{l}\text { Historical } \\
\text { maps }\end{array}$ & $\begin{array}{c}\text { Aerial } \\
\text { photographs }\end{array}$ & $\begin{array}{c}\text { Aerial } \\
\text { photographs }\end{array}$ & $\begin{array}{c}\text { Drawings } \\
\text { by Samuel } \\
\text { Birmann }\end{array}$ & $\begin{array}{c}\text { Historical } \\
\text { maps }\end{array}$ & $\begin{array}{c}\text { Aerial } \\
\text { photographs }\end{array}$ \\
\hline Length $[\mathrm{km}]$ & 10.2 & 8.4 & 8.2 & 15.7 & 14.2 & 12.0 \\
\hline Length change & \multicolumn{3}{|c|}{$19.6 \%(1860 / 61-2012)$} & \multicolumn{3}{|c|}{$23.6 \%(1821-2001)$} \\
\hline Area $\left[\mathrm{km}^{2}\right]$ & 26.1 & 20.6 & 17.7 & $\sim 46$ & 41.9 & 31.9 \\
\hline Area change & \multicolumn{3}{|c|}{$32.2 \%(1860 / 61-2012)$} & \multicolumn{3}{|c|}{$\sim 31 \%(1821-2001)$} \\
\hline $\begin{array}{l}\text { Elevation of head } \\
\text { [m a.s.1.] }\end{array}$ & 4,107 & 4,107 & 4,107 & 4,072 & 4,072 & 4,072 \\
\hline $\begin{array}{l}\text { Elevation of terminus } \\
\text { [m a.s.1.] }\end{array}$ & 972 & 1,297 & 1,365 & 1,087 & 1,379 & 1,467 \\
\hline $\begin{array}{l}\text { Absolute ice volume } \\
\text { change }\left[\mathrm{km}^{3}\right]\end{array}$ & \multicolumn{2}{|c|}{-1.56} & & & \multicolumn{2}{|c|}{-0.79} \\
\hline $\begin{array}{l}\text { Average thickness } \\
\text { change rate }\left[\mathrm{m} \mathrm{a}^{-1}\right]\end{array}$ & \multicolumn{2}{|c|}{-0.42} & & & \multicolumn{2}{|c|}{-0.31} \\
\hline
\end{tabular}




\section{Mer de Glace: the largest glacier of the Western Alps (historical records since the 16th century)}

The Mer de Glace ( $45^{\circ} 54^{\prime} \mathrm{N}, 6^{\circ} 57^{\prime} \mathrm{E}$; Fig. 1) is a 12-km long, $32 \mathrm{~km}^{2}$ compound valley glacier (as of 2001), making it the largest glacier in the Western Alps. It is formed by the confluence of the Glacier du Tacul, Glacier de Léschaux, and Glacier de Talèfre (disconnected since the mid-20th century), which together drain the northwestern flank of the Mont Blanc chain, situated in the French part of the massif. The glacier is formed from the firn areas that cover the heights directly north of Mont Blanc, several of which, as Grandes Jorasses, Aiguille Verte with Les Drus, Aiguille du Géant, Aiguille du Midi, and Mont Blanc du Tacul reach a height of about $4000 \mathrm{~m}$.

During the LIA, the Mer de Glace reached the Chamonix Valley bottom nearly continuously. Its dramatic setting and easy access made the glacier a popular objective for tourists, scientists, and artists, resulting in a large number of historical documents. The lowest flanks of the Mer de Glace, a large cascade of ice during the LIA visible from the valley of Chamonix, was called Glacier des Bois after the small village (Les Bois) which lies below. Today, the former Glacier des Bois has completely disappeared (Fig. 5; Nussbaumer et al., 2007).

Due to its central role in the history of alpinism, the Mont Blanc massif was the subject of several early studies, making it one of the best-documented mountain regions in the Alps. The first detailed descriptions of the area were made by the English travellers William Windham and Richard Pococke, followed by, among others, the Frenchman Pierre Martel and Genevois Marc Théodore Bourrit (Windham and Martel, 1744; Bourrit, 1787). Horace-Bénédict de Saussure set a milestone with his natural history masterpiece "Voyages dans les Alpes" (de Saussure, 1779-1796). These works contain the first descriptions of moraine ridges, glacier length fluctuations, and statements made by local people regarding the area's glaciers.

Apart from dendrochronological evidence (Le Roy et al., 2015), there exists little historical information about the Mer de Glace before the 17th century. However, by the end of the 16th century, there is clear evidence of a climate deterioration which led to glacier advances and severe damage to cultivated land in the Chamonix Valley (Le Roy Ladurie, 1967). Two hamlets close to the Mer de Glace - Bonanay and Le Châtelard were largely destroyed by the advancing glacier between 1601 and 1610 (Wetter, 1987). A brief retreat (for a few years) is documented around 1616, but the threat from the Glacier des Bois (Mer de Glace) persisted. In 1625, Le Châtelard was likely abandoned, and erased by the glacier in the early 1640s (Le Roy Ladurie, 1967; Nussbaumer et al., 2007). The Mer de Glace reached its maximum LIA extent following an impressive advance of 75-150 m per year between 1641 and 1643 according to contemporaneous reports (Mougin, 1912; Nussbaumer et al., 2007).

The dramatic advance was cause for a religious procession to bless the glacier in May 1644. The Glacier des Bois then retreated slightly until 1663, maintained an advanced position through the second half of the 17th century, retreated abruptly in the 1690s, then advanced again with equal intensity towards 1720 (Nussbaumer et al., 2007). 
An exceptional cadastral survey, conducted between 1728 and 1738, led to the first maps of the Chamonix Valley. The map sheet containing the Glacier des Bois, made in 1730, reveals that while the glacier tongue was still enlarged, it no longer posed an immediate threat to villages (Wetter, 1987). Nevertheless, the glacier tongue remained in the valley bottom, forming an impressive terminus with a vaulted cavern (de Saussure, 1779-1796).

From 1770 onwards, the history of the Mer de Glace is thoroughly documented thanks to the appearance of the first pictorial documents (drawings, paintings, and prints), beginning with the watercolour drawing by William Pars made on his journey through the Alps in 1770. Travel reports by Bordier (1773), Coxe (1789), Bourrit (1787) and de Saussure (1770-1796) provide evidence of an ongoing glacier advance which reached a maximum extent in 1778 . This advanced glacier position is noted by the German poet and naturalist Johann Wolfgang Goethe who visited the Mer de Glace in November 1779 (Nussbaumer et al., 2007).

A coloured contour etching by Carl Ludwig Hackert from 1780 or 1781 and a watercolour by Francis Towne from 1781 both depict the front of the Glacier des Bois with the source of the Arveyron River. The determination of the glacier front from these artworks suggests that the Glacier des Bois (Mer de Glace) was slightly retreating (Nussbaumer et al., 2007). Several artworks, including a drawing by Hans Conrad Escher von der Linth from 1785 and an impressive oil painting by Philippe Jacques de Loutherbourg - notably the teacher of C. Wolf - presumably made in 1787, confirm the reduced glacier extent, although the glacier was still reaching down to the plain and forming an impressive front. During this time, works by the prominent landscape artist Jean-Antoine Linck (1766-1843) from Geneva are of particular value for the LIA glacier history. Linck visited the Chamonix Valley and its glaciers on several journeys and depicted both the retreated stage of the Mer de Glace before 1800 (Nussbaumer et al., 2007) and the subsequent re-advance at the beginning of the 19 th century (Fig. 4a).

The influential watercolour by Joseph Mallord William Turner in 1802 brought the Mont Blanc area once again to the attention of English travellers and artists. It confirms the full re-advance of the Glacier des Bois, as also seen in a huge gouache by J.-A. Linck from around 1810 (Nussbaumer et al., 2007). Texts collected by Le Roy Ladurie (1967) independently confirm a glacier advance from 1805 to 1814. According to the findings of Viollet-le-Duc (1876), from 1812 to 1817 the winters were long and severe in the valley of Chamonix and the summers were wet, particularly in 1816, the infamous "year without a summer" which followed the 1815 eruption of Mount Tambora (Brönnimann and Krämer, 2016). Consistent with these meteorological observations, the Mer de Glace advanced during this period (mainly between 1810 and 1820) to just $40 \mathrm{~m}$ short of the 1644 LIA maximum, as documented by several drawings by J.-A. Linck (made around 1820) and S. Birmann (made in 1823). Birmann was full of enthusiasm for the Glacier des Bois and praised the glacier as one of the most interesting and easily accessed in the Alps. Moreover, his notebook contains detailed descriptions of the glacier approaching the village of Les Bois by 20 steps before retreating after 1821 
(Birmann, 1826). Several photographically accurate drawings by Birmann made from different viewing positions allow a meticulous reconstruction of the glacier margin in 1823 (Fig. 4b).

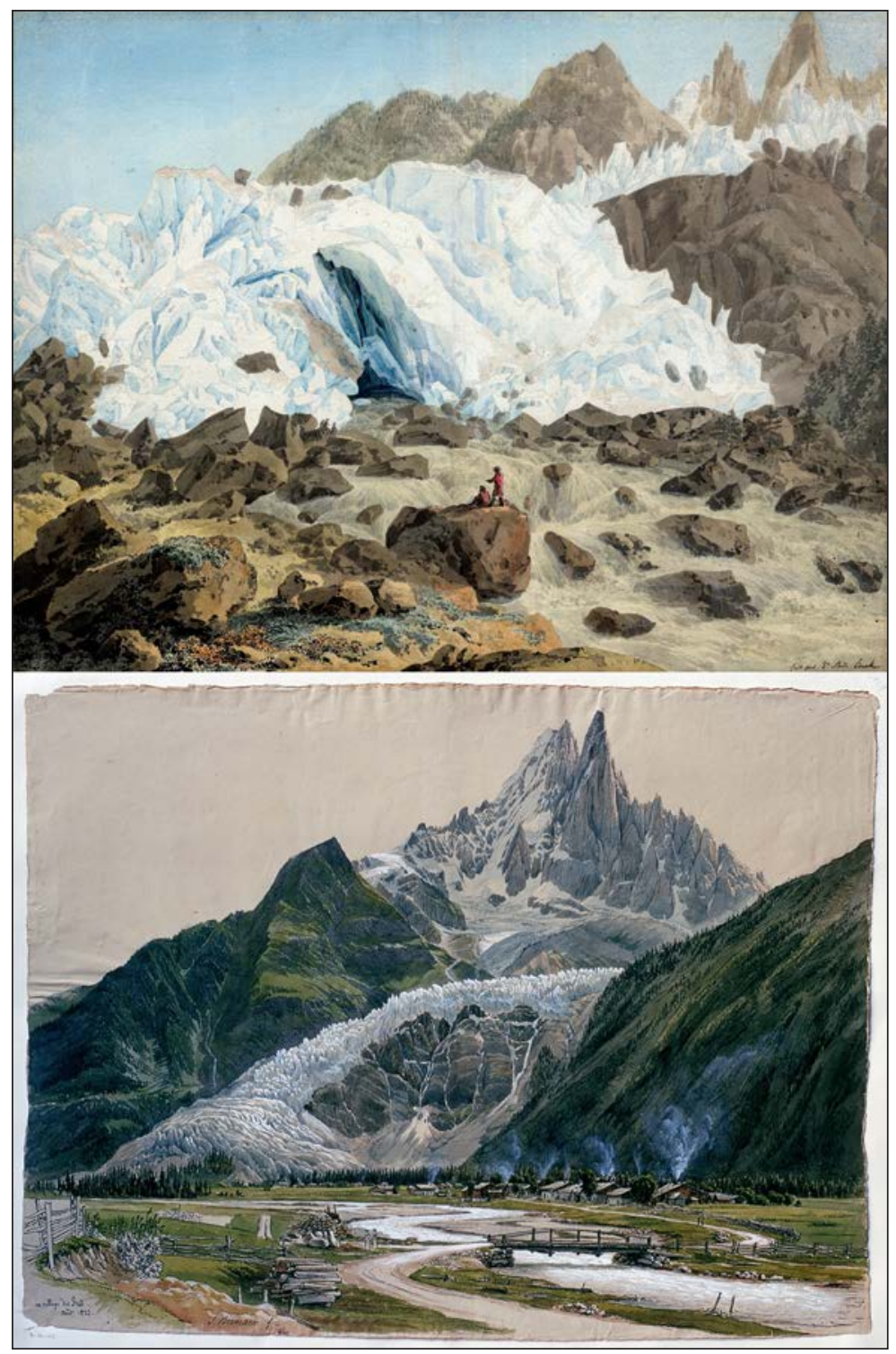

Figure 4. Frontal view of the Mer de Glace (a) around 1804, drawn with pencil, watercolour and gouache by J.-A. Linck (private collection) and (b) in August 1823, drawn with pencil, pen, watercolour, and opaque white by S. Birmann, with the village of Les Bois in the foreground (Kunstmuseum Basel, Kuperstichkabinett). 
The 1820 advance represents the second largest extent of the Mer de Glace during the LIA. Another advance followed around 1852, and both advances are documented by moraine deposits (Nussbaumer et al., 2007). During this time, pioneering glaciological studies were carried out at the Mer de Glace by James David Forbes, resulting (among other things) in the first detailed map of the glacier in 1842 (Forbes, 1843). Detailed descriptions of the Mer de Glace in 1850/51 are available from Joseph Vallot, in particular the report of a contemporaneous witness that the glacier reached within $50 \mathrm{~m}$ of Les Bois (Vallot, 1900).

Starting in the mid-1850s, the Mer de Glace began to retreat rapidly (Fig. 10c), only interrupted by a small advance around 1867 . The retreat is very well documented by an abundance of early photographs (Nussbaumer et al., 2012), and by the outstanding drawings, sketches, and map made by the French architect Eugène Viollet-le-Duc (1814-1879) during his studies in the Chamonix Valley from 1868 to 1875 (Viollet-leDuc, 1876). Since 1878, continuous systematic measurements of the glacier front are available (Mougin, 1912; Payot, 1884), measurements which have continued to today. The glacier front position was stable from the 1880s to 1931, retreated by $818 \mathrm{~m}$ from 1931 to 1969, and advanced by 143 m from 1969 to 1995 - forming a small frontal moraine that is still visible today. From 1995 until 2015, the glacier retreated by 728 m (WGMS, 2017).

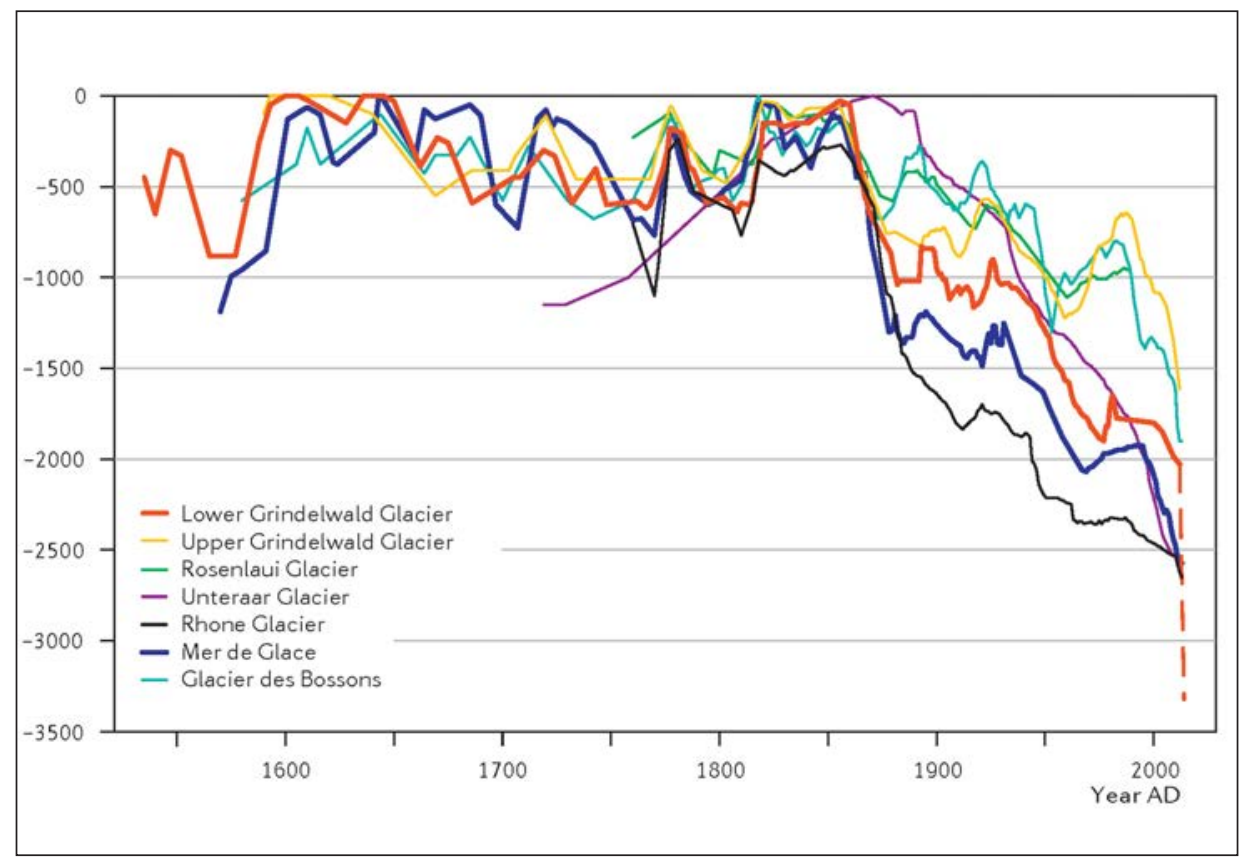

Figure 5. Glacier length changes based on historical documents (data: Zumbühl, 1980; Zumbühl et al., 1983, 2008; Zumbühl and Holzhauser, 1988; Nussbaumer et al., 2007; Nussbaumer und Zumbühl, 2012). 


\section{Glaciers and human beings - perception and reflection}

For centuries, glaciers have fascinated human observers. In the Medieval and Early Modern periods, the advancing masses of glacier ice were seen as a weird, wild, and terrific threat. By the early 18th century, this perception changed, the myth of the Alps - the white and radiant "eternal firn" - became the symbol of an attracting, pure, untouched, healing and holy nature, close to the sky, provider of water and life.

Only after the concept of landscape was "discovered" by the artists of the early Renaissance in Tuscany and Flanders could this vision be fully realized. Their focus on pictorial representation and use of linear perspective are responsible for the "invention" of the landscape in the modern sense. Glacier landscapes exemplified "real nature landscapes" and pictorial documents on the subject of glaciers were created as early as the 17 th century.

At the turn of the 16th to the 17th century, several glaciers in the Alps experienced large and long-lasting advances that resulted in the loss of agricultural lands. In Austrian Tyrol, the inhabitants of the Ötz Valley were exposed to a high risk of catastrophic flooding by the rapid discharge of the glacier lake formed by the very fast (surge type) advances of Vernagtferner (Nicolussi, 2013). The Emperor called a commission, which drew several plans and panoramic views of the glacier and the lake, including floating icebergs (e.g., 1601, 1678, and 1681). These drawings are probably the oldest pictorial documents of glaciers in the Alps (Fig. 6) and realized in a naturalistic style (striving for accuracy and objectivity).

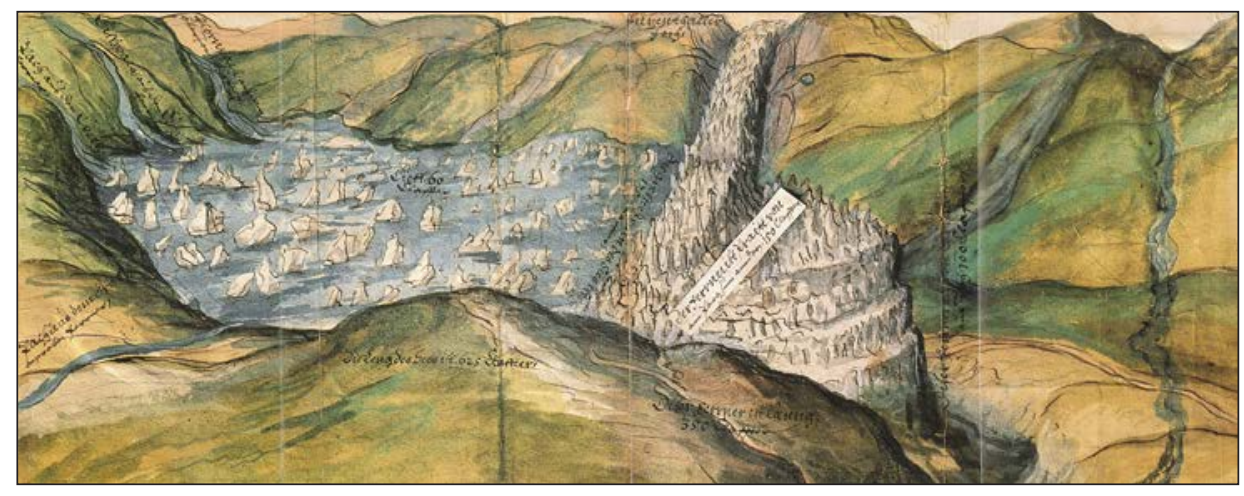

Figure 6. View of Vernagtferner damming a glacial lake in the Ötz Valley on 9 July 1601 (watercolour with pen; Tiroler Landesmuseum Ferdinandeum, Innsbruck; Nicolussi, 2013).

In 1669 and in a similar style, A. Kauw made a very fine, watercolour pen drawing representing a panorama of Grindelwald including the Lower and Upper Glaciers. The Lower Grindelwald Glacier is marked with dark-blue pyramids and terminates in the valley bottom about $250 \mathrm{~m}$ behind the moraines of the 1602 LIA maximum (Fig. 2a). Of special interest is a written comment in the legend: "Die Eÿss schropfen so wachsen” (the ice pyramids, or seracs, are growing), indicating that the glacier was advancing. The detail-oriented artist also added lateral moraines drawn in light-tan alongside the stream of ice. 


\subsection{Idealistic-realistic glacier landscapes}

Glaciers became a central subject for artists during the age of Enlightenment. Caspar Wolf (1735-1783) was the most important Swiss painter of the Alps in this period. Trained in Paris by the famous Joseph Vernet (well known for his fantastic seascapes), Wolf was commissioned to produce about 200 paintings, which he performed from 1773/74 to 1779. Of these, 61 depict glaciers in the Bernese Alps, mostly advancing at the time. These masterpieces show in an impressive way how glacier landscapes can be presented scientifically precise but also artistically idealized.

On his travels to the high Alps, Wolf was often accompanied by either his editor or a naturalist, both from Berne, Switzerland. They introduced him to a new view on the nature of mountains in the age of Enlightenment. As a result, Wolf painted on site, precisely depicting the geomorphology, the rocky and icy terrain, changing ice caves at the glacier front, the waterfalls - sometimes even in winter. Wolf was one of the courageous first artists to venture deep into the high Alps. He climbed the Bänisegg (2040 m) above the Lower Grindelwald Glacier from where he painted three oil sketches and three paintings (Fig. 7b, cut-out), which together form probably the oldest high mountain panorama (Zumbühl et al., 2016). As seen in this panorama and many of his other paintings, Wolf often included tiny human figures, being amazed by the impressive huge mountain peaks covered with ice, topped by the blue sky above (Figs. 7a/b/c, cut-outs).
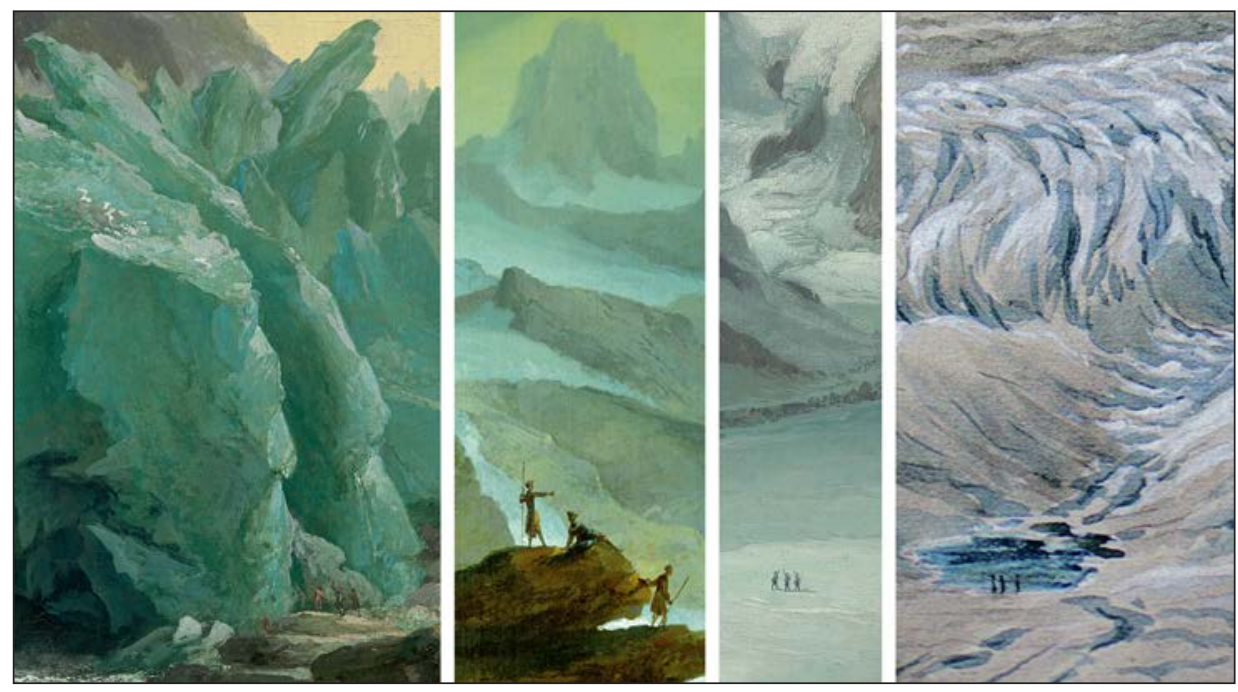

Figure 7. Human beings and glaciers: (a) Front of the Lower Grindelwald Glacier by C. Wolf in 1774 and/or 1776/77 (cut-out; oil on canvas; Museum Oskar Reinhart, Winterthur), (b) panorama from the Bänisegg by C. Wolf, with Schreckhorn in 1774-1778 (cut-out; oil on canvas; private collection), (c) Finsteraar Glacier by C. Wolf in 1774 (cut-out; oil on canvas; private collection), and (d) Mer de Glace near Montenvers by S. Birmann on 5 August 1823 (cut-out; pencil, pen, watercolour, opaque white; Kunstmuseum Basel, Kupferstichkabinett). 


\subsection{Romantic-realistic glacier landscapes}

Starting in 1789, the artist Jean-Antoine Linck (1766-1843) traveled throughout the Alps from Savoy to St Gotthard, drawing landscapes - with special preference of ice regions, which he drew with naturalistic correctness and alpinist daring. The drawings representing landscapes show the most personal aspect of the work of Linck, showing very precisely and in an objective way the structures and nature of objects, renewing in some way the approach of C. Wolf (Nussbaumer et al., 2007). Uniquely, Linck drew the same glaciers over time, such as the Glacier de Bois, which he drew retreating at the end of the 18th century and again, this time advancing, probably in 1804 (a watercolour and gouache drawing of the advancing glacier disintegrated by crevasses and a glacier snout partly caved in; Fig. 4a).

Several other artists created beautiful paintings and drawings in romanticrealistic style in the late 18th and early 19th centuries, including Joseph Anton Koch, Franz Niklaus König, Johann Jakob Biedermann, and in the years 1835-1838 Thomas Fearnley (Zumbühl et al., 2016), and the great master of topographical landscape art, Samuel Birmann (1793-1847). Alongside his unique collection of photographically precise glacier sketches, Birmann also created some very romantic, composed landscapes, featuring real elements but from different study sites. A large watercolour pen drawing from 1829 (Fig. 8), dominated by Schreckhorn stretched vertically to a bizarre crown of rocky peaks, presents various glacial phenomena (e.g., ice cave, crevasse, glacier table) of the Lower Grindelwald Glacier in the area of Ischmeer and Zäsenbergalp, with the mountain hut, a sign of the presence of human beings. Several chamois hunters try to climb or to walk on the glacier. This idealized scene of exaggerated relief of the high Alps, dwarfing a small, insignificant human presence is typical of the landscape art of the Romanticism. All these pictorial documents prove that both the Lower and Upper Grindelwald Glaciers are ending continuously with the tongues down in the valley bottom until the 1850 s, the end of LIA. 


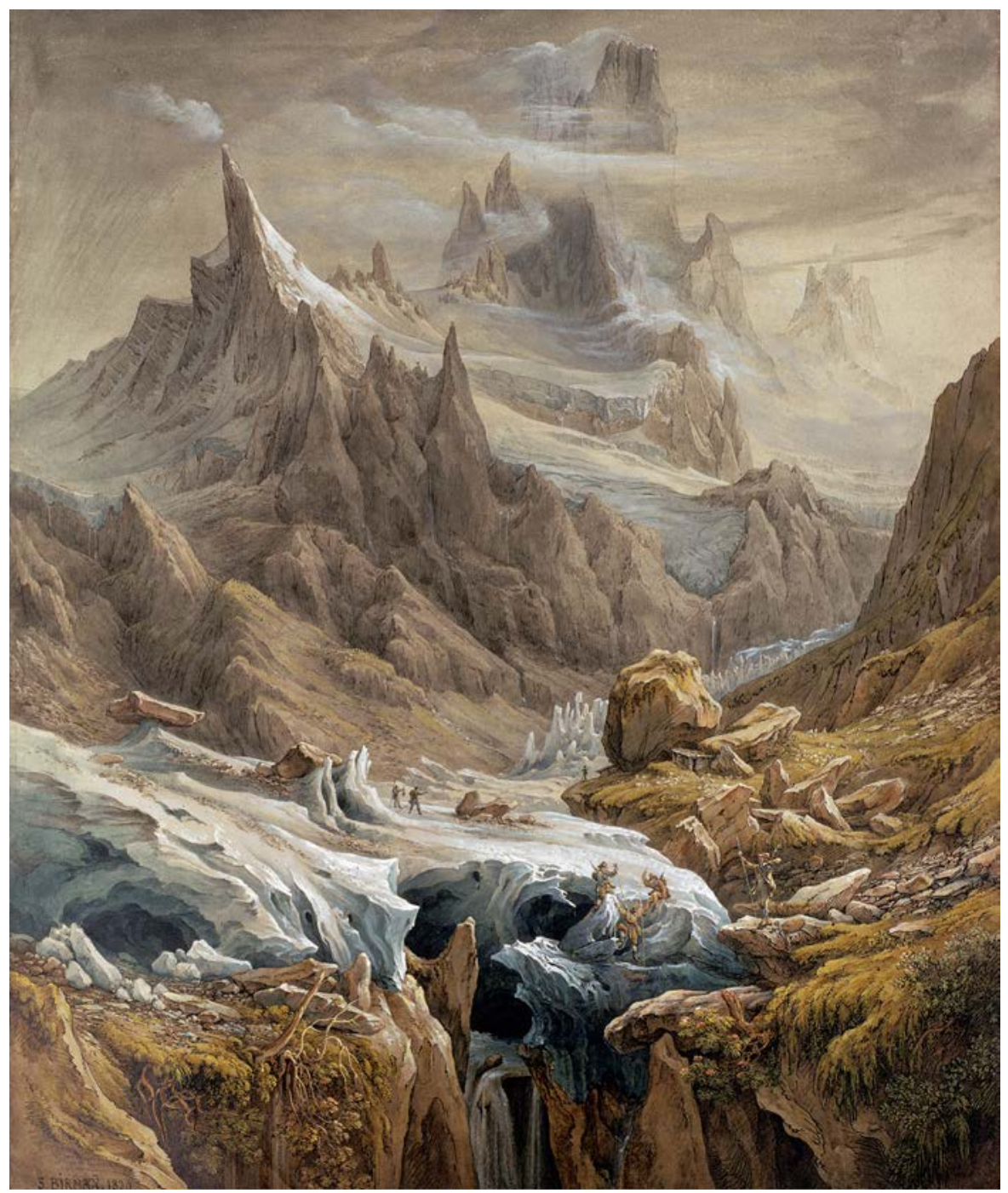

Figure 8. Paysage composé by S. Birmann: Ischmeer (Lower Grindelwald Glacier) with Schreckhorn, Zäsenbergalp (right), glacier snout, randkluft, and chamois hunters (1829; pen drawing with watercolour and gouache; Kunstmusem Basel, Kupferstichkabinett).

\subsection{Surveyed and photographed glacier landscapes}

Three important scientific and technical innovations emerged in the 1840s and changed the interpretation and representation of glaciers in a sustainable way in the following decades: 
(i) The development of the ice age theory and the gradual and ongoing process of its acceptance in the 1850s (Krüger, 2013).

(ii) The revolutionary advances in photographic reproduction in the middle of the 19th century. With photography, glaciers could be represented in a much more objective way than with drawings, paintings, etchings or lithographs. A growing number of photographers experimented with different techniques and materials for photographing mountain glaciers, an endeavour which was mostly difficult and costly. Notable early examples include the $1.85 \mathrm{~m}$-wide panoramic photograph of Finsteraar and Lauteraar Glaciers by Auguste Rosalie Bisson, which became famous because of the world exhibition in Paris. Other important documents are the large panorama of Grindelwald by Aimé Civiale (Zumbühl et al., 2016), the smaller glass-plate negatives of the Lower and Upper Grindelwald Glaciers by Frédéric Vincent de Martens from the 1850s (Fig. 10a), and the stereophotographs of glaciers by Adolphe Braun from the 1860s which, because of the spectacular 3-dimensional effect, small size, and low cost, were popular with the growing number of tourists.

(iii) The advances in cartography and surveying starting in the 1840s. Louis Agassiz (1807-1873), professor at the University of Neuchâtel, conducted a research programme at the Unteraar Glacier between 1840 and 1845 that marks the beginning of modern experimental glaciology. The study, performed by an interdisciplinary team, was in part to support Agassiz' theory of ice ages. In 1842, Agassiz and geometrician Johannes Wild realized a map of Unteraar Glacier at 1:10,000 scale (Agassiz, 1847), probably the first detailed scientific map of a glacier. This lithograph in black and blue, an aesthetic masterpiece, depicts $8 \mathrm{~km}$ of the glacier tongue with a large number of surface glaciological features and a representation of surface slopes by a system of hatched lines (Zumbühl and Holzhauser, 1988). Another research team member, artist Jacques Bourckhardt, drew a very precise panorama in 1842 of the Lauteraar and Finsteraar Glaciers from Mieselenegg, including the "Hôtel des Neuchâtelois" - a big boulder and besides a tent where Agassiz, his collaborators, and visitors lived during the research campaigns (Fig. 9a/c, cut-out).

In the same year, James David Forbes (1809-1868), professor of natural philosophy at the University of Edinburgh known for his work on glacier movement, carried out surveys and triangulations in the Mont Blanc massif, especially around the Mer de Glace, and published a map at 1:25,000 scale (Forbes, 1843). Notably, the aforementioned maps all lacked contour lines.

The art and science of cartography would finally join together in 1874, when the architect Eugène Viollet-le-Duc (1814-1879) drew an illustrated map of the Mont Blanc massif whose superb colouration evokes more a painting than a map (Frey, 1988). To complete his map, Viollet-le-Duc availed himself of existing maps by Dufour, Mieulet, Adams-Reilly, and photographs by Civiale and the Bisson brothers. The accompanying meticulous sketches and drawings are based on his own surveys and of an unparalleled precision. 

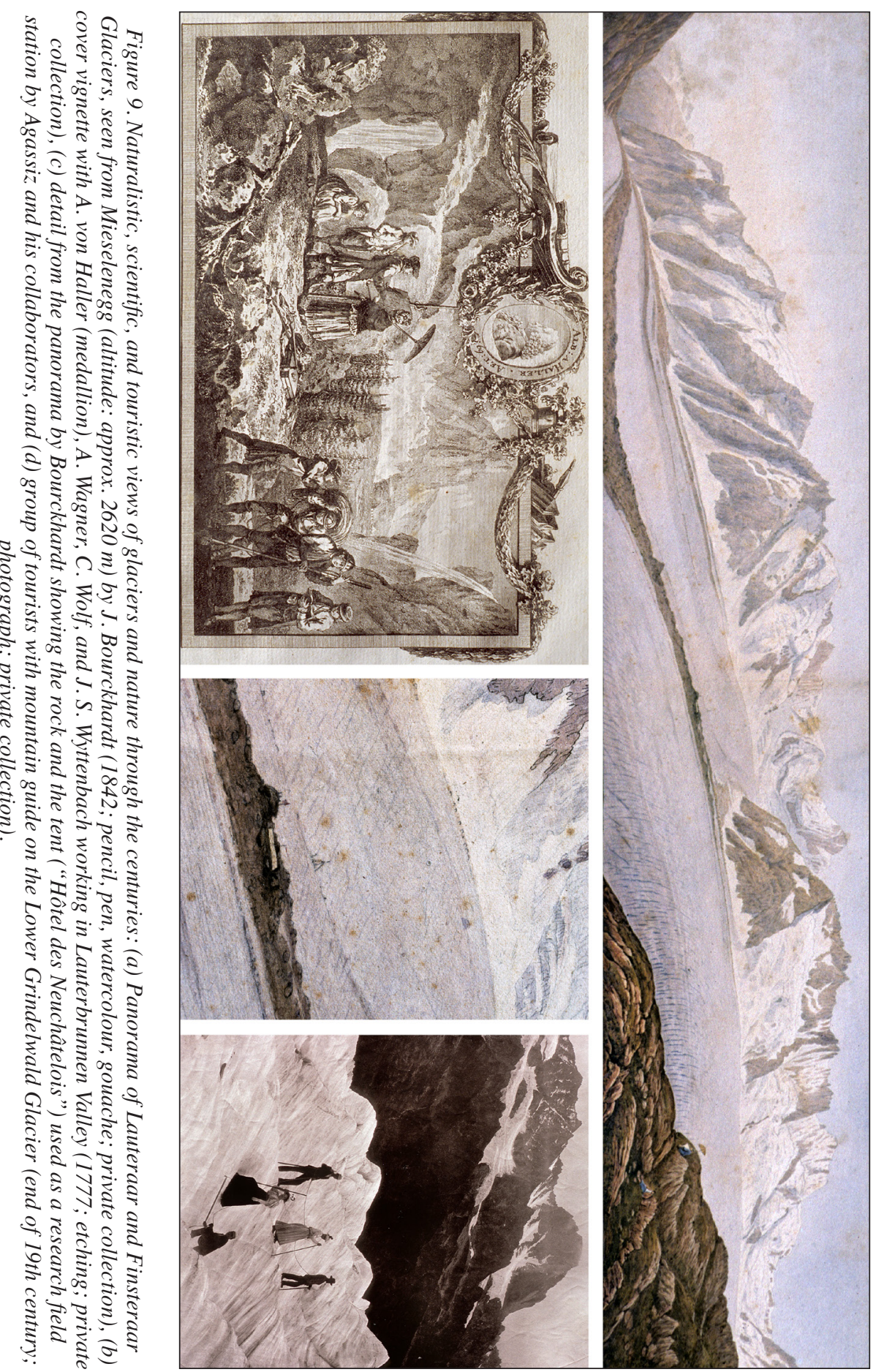


\subsection{Glaciers as top attraction of the Alps and in the 21st century disappearing from sight}

The second half of the 19th and the early 20th centuries were characterized by a growing number of photographers, an explosion in the number of tourists, the construction of mountain trains (the Jungfrau Railway in the Bernese Alps, the train to Montenvers/Mer de Glace in the Mont Blanc area) and cable-cars (from Grindelwald to Wetterhorn, only partly realized, and from Chamonix to Aiguille du Midi), and the initiation of continuous scientific glacier measurements - since 1878 at the Mer de Glace (Mougin, 1912) and since 1879 for the Lower Grindelwald Glacier by the Swiss Academy of Sciences (Glaciological reports, 1881-2017). All these trends contributed to glaciers becoming among the most sought after objects in the Alps. Visiting the Alps meant in large part to see and climb onto a glacier, if only to visit an ice cave at the glacier terminus, and to memorialize the visit with a great number of photographs. However, the glory of ice in the Alps as it was to admire during the LIA and partially in the first half of the 20th century, is confined to history.
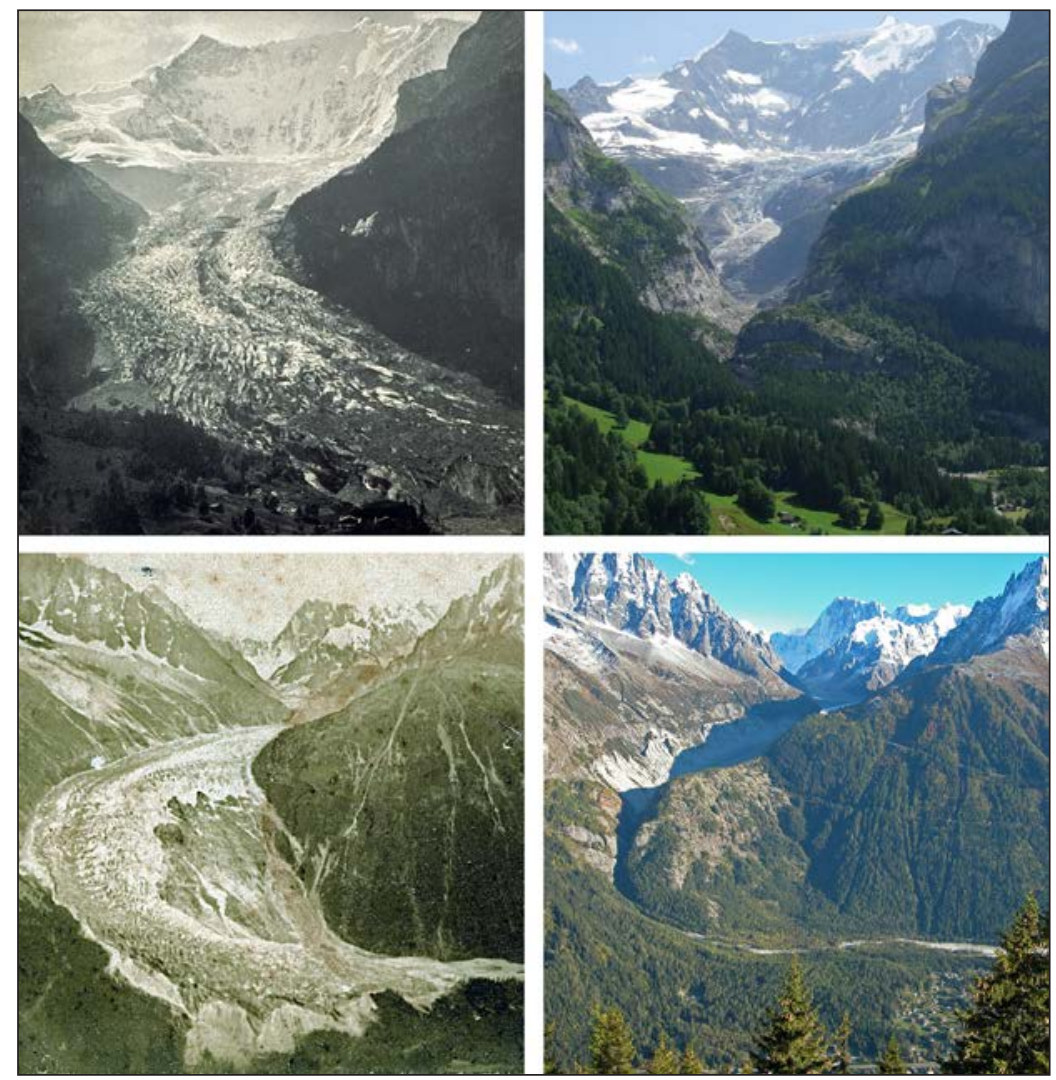

Figure 10. Lower Grindelwald Glacier (a) in the valley floor in 1858 (1856?), by F. V. de Martens (photograph; Alpine Club Library, London) and (b) in 2013 (photo: S. U. Nussbaumer). Mer de Glace seen from La Flégère by (c) H. Plaut in the 1850s (stereophotograph; private collection) and (d) in 2005 (photo: S. U. Nussbaumer). 


\section{Conclusions}

(i) With a huge number of high-quality pictorial documents, it is possible to reconstruct the LIA history of many glaciers in the European Alps, starting in the 17 th century and more precisely in the 18th/19th centuries. In this context, we focussed on the Lower Grindelwald Glacier in the Bernese Oberland and the Mer de Glace in the Mont Blanc massif.

(ii) Thanks to these pictorial documents, we get an image of the beauty and fascination of the LIA glaciers with their advancing, steep frontal zones down in the valley bottom near villages and threatening their habitants.

(iii) The pictorial documents (drawings, paintings, prints, photographs and maps) of important artists (e.g., C. Wolf, J.-A. Linck, S. Birmann, the Bisson brothers, F. V. de Martens, A. Braun, J. Beck) were promoting the glaciers, and consequently more and more people wanted to directly see on site these wonders of nature. This resulted in a rapidly growing tourism in the Alps.

(iv) A comparison of the LIA pictorial documents with the same views of today shows a dramatic reduction of glaciers, a totally different landscape. It is probably the best and most impressive visual proof for the changes in climate.

(v) Today, aerial, satellite, and ground-based images depict in astonishing detail the steady retreat of the world's glaciers - no doubt one of the most stunning and devastating worldwide trends. With wide-ranging implications to landscapes and to society, we are "saying goodbye to glaciers" (Moon, 2017).

\section{Acknowledgements}

We thank Ethan Welty for English language corrections. The comments and suggestions from the reviewers are greatly appreciated. Many institutions and archives provided access to the iconographic material. If not otherwise specified, historical documents were reproduced by the authors.

\section{References}

Agassiz, L. (Guyot, A./Desor, E.) 1847. Système glaciaire ou recherches sur les glaciers, leur mécanisme, leur ancienne extension et le rôle qu'ils ont joué dans l'histoire de la terre. Première partie: Nouvelles études et expériences sur les glaciers actuels, leur structure, leur progression et leur action physique sur le sol. V. Masson, Paris, L. Voss, Leipzig, 2 vols.

Birmann, S. 1826. Souvenirs de la vallée de Chamonix. Birmann et fils, Basle.

Bordier, A.-C. 1773. Voyage pitoresque aux glacières de Savoye. Fait en 1772. Caille, Genève, 303 pp.

Bourrit, M.T. 1787. Nouvelle description des glacières, vallées de glace et glaciers qui forment la grande chaîne des Alpes de Savoye, de Suisse et d'Italie. Barde, Genève, 3 vols.

Brönnimann, S., Krämer, D. 2016. Tambora and the "Year Without a Summer" of 1816. A perspective on Earth and human systems science. Geographica Bernensia G90. Institute of Geography, University of Bern, 48 pp. http://doi.org/10.4480/GB2016.G90.01.

Coxe, W. 1789. Travels in Switzerland in a series of letters to William Melmoth. Cadell, London, 3 vols. De Saussure, H.-B. 1779-1796. Voyages dans les Alpes. S. Fauche, Neuchâtel, 4 vols. 
Forbes, J.D. 1843. Travels through the Alps of Savoy and other parts of the Pennine chain with observations of the phenomena of glaciers. Adam and Charles Black, Edinburgh, 424 pp.

Frey, P.A. (Ed.) 1988. E. Viollet-le-Duc et le massif du Mont-Blanc 1868-1879. Editions Payot, Lausanne, $160 \mathrm{pp}$.

Glaciological reports 1881-2017. The Swiss Glaciers. Yearbooks of the Cryospheric Commission of the Swiss Academy of Sciences (SCNAT), published since 1964 by the Laboratory of Hydraulics, Hydrology and Glaciology (VAW) of ETH Zürich, No. 1-136, http://glaciology.ethz.ch/swissglaciers/.

Grove, J.M. 2004. Little ice ages: ancient and modern. 2nd edition. Routledge, London and New York, 2 vols. http://doi.org/10.4324/9780203770245.

Holzhauser, H., Zumbühl, H.J. 1996. To the history of the Lower Grindelwald Glacier during the last 2800 years - palaeosols, fossil wood and historical pictorial records - new results. Zeitschrit für Geomorphologie N. F. Suppl. 104, 95-127.

Holzhauser, H., Zumbühl, HJ. 2003. Nacheiszeitliche Gletscherschwankungen. In: R. Weingartner, M. Spreafico (Eds.), Hydrologischer Atlas der Schweiz. Special edition for the 54th "Deutscher Geographentag" in Berne. Bundesamt für Landestopographie, Bern-Wabern, Tafel 3.8.

IPCC 2013. Climate change 2013: the physical science basis. Contribution of Working Group I to the Fifth Assessment Report of the Intergovernmental Panel on Climate Change. T.F. Stocker, D. Qin, G.-K. Plattner, M. Tignor, S. K. Allen, J. Boschung, A. Nauels, Y. Xia, V. Bex, and P. M. Midgley (Eds.), Cambridge University Press, Cambridge and New York, 1535 pp.

Krüger, T. 2013. Discovering the Ice Ages: international reception and consequences for a historical understanding of climate. Brill, Leiden, $534 \mathrm{pp}$.

Le Roy Ladurie, E. 1967. Histoire du climat depuis l'an mil. Flammarion, Paris, 379 pp.

Le Roy, M., Nicolussi, K., Deline, P., Astrade, L., Edouard, J.-L., Miramont, C., Arnaud, F. 2015. Calendar-dated glacier variations in the western European Alps during the Neoglacial: the Mer de Glace record, Mont Blanc massif. Quaternary Science Reviews 108, 1-22. http://doi.org/10.1016/j. quascirev.2014.10.033.

Marzeion, B., Cogley, J.G., Richter, K., Parkes, D. 2014. Attribution of global glacier mass loss to anthropogenic and natural causes. Science 345 (6199), 919-921. http://doi.org/10.1126/ science. 1254702 .

Moon, T. 2017. Saying goodbye to glaciers. Science 356 (6338), 580-581. http://doi.org/10.1126/science. aam9625.

Mougin,P. 1912. Etudes glaciologiques. Savoie - Pyrénées. Tome III. Imprimerie Nationale, Paris, 166 pp.

Nicolussi, K. 2013. Die historischen Vorstösse und Hochstände des Vernagtferners 1600-1850 AD. Zeitschrift für Gletscherkunde und Glazialgeologie 45/46, 9-23.

Nussbaumer, S.U., Deline, P., Vincent, C., Zumbühl, H.J. (Eds.) 2012. Mer de Glace - Art \& science. Atelier Ésope, Chamonix, 192 pp.

Nussbaumer, S.U., Zumbühl, H.J. 2012. The Little Ice Age history of the Glacier des Bossons (Mont Blanc massif, France): a new high-resolution glacier length curve based on historical documents. Climate Change 111 (2), 301-334. http://doi.org/10.1007/s10584-011-0130-9.

Nussbaumer, S.U., Zumbühl, H.J., Steiner, D. 2007. Fluctuations of the Mer de Glace (Mont Blanc area, France) AD 1500-2050. Part I: The history of the Mer de Glace AD 1570-2003 according to pictorial and written documents. Zeitschrft für Gletscherkunde und Glazialgeologie 40, 5-140.

PAGES 2k Consortium 2013. Continental-scale temperature variability during the past two millennia. Nature Geoscience 6 (5), 339-346. http://doi.org/10.1038/ngeo1797.

Payot, V. 1884. Oscillations des quatre grands glaciers de la vallée de Chamonix et énumération des ascensionnistes au Mont-Blanc. Sandoz, Genève. 
Solomina, O.N., Bradley, R.S., Hodgson, D.A., Ivy-Ochs, S., Jomelli, V., Mackintosh, A.N., Nesje, A., Owen, L.A., Wanner, H., Wiles, G.C., Young, N.E. 2015. Holocene glacier fluctuations. Quaternary Science Reviews 111, 9-34. http://doi.org/10.1016/j.quascirev.2014.11.018.

Steiner, D., Zumbühl, H.J., Bauder, A. 2008. Two Alpine glaciers over the past two centuries: a scientific view based on pictorial sources In: B. Orlove, E. Wiegandt, B.H. Luckman, (Eds.), Darkening peaks: glacier retreat, science, and society. University of California Press, Berkeley, pp. 83-99.

Vallot, J. 1900. Annales de l'observatoire météorologique, physique et glaciaire du Mont Blanc. Tome 4. Steinheil, Paris, 189 pp.

Viollet-le-Duc, E. 1876. Le massif du Mont Blanc. Etude sur sa constitution géodésique et géologique, sur ses transformations et sur l'état ancien et moderne de ses glaciers. Baudry, Paris, 280 pp.

Wetter, W. 1987. Spät- und postglaziale Gletscherschwankungen im Mont Blanc-Gebiet: Untere Vallée de Chamonix - Val Montjoie. Physische Geographie 22. Geographisches Institut der Universität Zürich, $267 \mathrm{pp}$.

WGMS 2017. Global Glacier Change Bulletin No. 2 (2014-2015). M. Zemp, S.U. Nussbaumer, I. Gärtner-Roer, J. Huber, H. Machguth, F. Paul, M. Hoelzle (Eds.), ICSU(WDS)/IUGG(IACS)/ UNEP/UNESCO/WMO, World Glacier Monitoring Service, Zürich. http://doi.org/10.5904/wgmsfog-2017-06.

Windham, W., Martel, P. 1744. An account of the glacières or ice Alps in Savoy. In two letters. As laid before the Royal Society, London.

Zemp, M., Frey, H., Gärtner-Roer, I., Nussbaumer, S.U., Hoelzle, M., Paul, F., Haeberli, W., Denzinger, F., Ahlstrøm, A.P., Anderson, B., Bajracharya, S., Baroni, C., Braun, L.N., Cáceres, B.E., Casassa, G., Cobos, G., Dávila, L.R., Delgado Granados, H., Demuth, M.N., Espizua, L., Fischer, A., Fujita, K., Gadek, B., Ghazanfar, A., Hagen, J.O., Holmlund, P., Karimi, N., Li,Z., Pelto, M., Pitte, P., Popovnin, V.V., Portocarrero, C.A., Prinz, R., Sangewar, C.V., Severskiy, I., Sigurhssson, O., Soruco, A., Usubaliev, R., Vincent, C. 2015. Historically unprecedented global glacier decline in the early 21st century. Journal of Glaciology 61 (228), 745-762. http://doi.org/10.3189/2015JoG15J017.

Zumbühl, HJ. 1980. Die Schwankungen der Grindelwaldgletscher in den historischen Bild- und Schriftquellen des 12. bis 19. Jahrhunderts. Ein Beitrag zur Gletschergeschichte und Erforschung des Alpenraumes. Denkschriften der Schweizerischen Naturforschenden Gesellschaft 92, 279 pp. http://doi.org/10.1007/978-3-0348-6546-3.

Zumbühl, H.J. 1997. Die Hochgebirgszeichnungen von Samuel Birmann - ihre Bedeutung für die Gletscher- und Klimageschichte. Katalog zur Ausstellung "Peter und Samuel Birmann - Künstler, Sammler, Händler, Stifter” des Kunstmuseums Basel vom 27.09.1997-11.01.1998, Schwabe, Basel, pp. 59-74.

Zumbühl, H.J. 2009. "Der Berge wachsend Eis...” Die Entdeckung der Alpen und ihrer Gletscher durch Albrecht von Haller und Caspar Wolf. Mitteilungen Naturforschenden Gesellschaft Bern N. F. 66, 105-132.

Zumbühl, HJ., Holzhauser, H. 1988. Alpengletscher in der Kleinen Eiszeit. Sonderheft zum 125 jährigen Jubiläum des SAC. Alpen 64 (3), 129-322.

Zumbühl, H.J., Messerli, B., Pfister, C. 1983. Die Kleine Eiszeit: Gletschergeschichte im Spiegel der Kunst. Katalog zur Sonderausstellung des Schweizerischen Alpinen Museums Bern und des Gletschergarten-Museums Luzern vom 09.06.-14.08.1983 (Luzern), 24.08.-16.10.1983 (Bern), 60 pp.

Zumbühl, H.J., Nussbaumer, S.U., Holzhauser, H., Wolf, R. (Eds.) 2016. Die Grindelwaldgletscher Kunst und Wissenschaft. Haupt, Bern, 256 pp.

Zumbühl, H.J., Steiner, D., Nussbaumer, S.U. 2008. 19th century glacier representations and fluctuations in the central and western European Alps: An interdisciplinary approach. Global and Planetary Change 60 (1-2), 42-57. http://doi.org/10.1016/j.gloplacha.2006.08.005. 